\title{
Cytogenetic effect of industrial and agricultural wastes on Tilapia zilli fish
}

\author{
Mohamed E.M.Zowail ${ }^{1}$; Magda M. Elezaby ${ }^{1}$; Aml M. Abdel-kareim ${ }^{1}$; \\ Ghada A. Yousef ${ }^{2}$ and Amany A. Mahmoud ${ }^{1}$ \\ 1- Zoology Department, Faculty of Science, Benha University, Benha, Egypt \\ 2- Zoology Department, Faculty of Science, Menuifiya University, Menuifiya, Egypt
}

\section{ABSTRACT}

The River Nile and its branches are exposed to many kinds of chemicals and biological pollutants as a result of increasing industrial and biological pollutants and other urbanization activates where effluents are discharged directly into the water without prior treatment.

This study aimed to clarify the effect of environmental pollution (Industrial and agricultural pollutions) on some genetic processes of Tilapiane fish. The study included three groups. The first group was collected from unpolluted locality, the second group collected from downstream to the mouth of agricultural discharge, and the third group was collected from downstream. Chromosomal aberrations were used as an index to evaluate the relationship between the genetic processes and the effect of water pollution. Water analysis was done to water samples from seven localities to determine the following metals iron, lead, cadmium, copper, zinc, mercury and nickel. The results showed that the mean of all metals in the unpolluted water were within the acceptable permissible limit of WHO. In the agricultural polluted water, $100 \%$ of water samples exceeding the permissible limit for iron, lead, cadmium, nickel and mercury. Whereas zinc and copper were within the permissible limit. Both industrial and agricultural water, pollutions caused an increase in the frequency of chromosomal aberrations but the frequency in industrial pollution was higher than in agricultural pollution. The types of aberrations observed in this study were structural and numerical aberrations. The predominant types of aberrations by exposure to agricultural pollution were deletion, gap and end to end association and the predominant types of aberrations by exposure to industrial pollution were centromeric attenuation, break and ring. Both industrial and agricultural water pollutions caused a significant increase in the frequency of fragmentation, polyploidy, stickiness and monosomy.

Keywords:

\section{INTRODUCTION}

Pollution of rivers and streams with chemical contaminations has become one of the most crucial environmental has become one of the most crucial environmental problems within the 20 the century. The variety of problems, particularly heavy metals which known to be toxic to human beings as well as to aquatic organisms, are enormous. Bioaccumulation of heavy metals in fish may critically influence both growth rate and quality of fish (Hodson et al., 1984؛ Haggag et al., 1999 and Zaghloul, 2001). In Egypt, Tilapiane fish represented one of the most common species in river Nile and numerous lakes. Consequently special interest has given to study the physiological, genetical and environmental conditions related to improve Tilapia production (Pullin and Meconnell, 1982). Exposure to heavy metals even in low 
concentrations affects survival of fish and other aquatic organisms. Several studies have linked increases in cytogenetic abnormalities in fish and shellfish to polluted environments. This was done largely through laboratory bioassays of polluted sample in nature (Alink et al., 1980; Hose et al., 1987) Also Karima and Halima (2002) reported that water pollution (Industrial and agricultural waste water) have a significant effects on Clarias lazera and Oreochromis niloticus which appeared as chromosomal aberrations in somatic cells and a significant increase in germ cells that appeared as $x-y$ univalent. The aim of the current study is to throwing head lights over the problem of water pollution with heavy metals due to industrial and agricultural drainages. Also to clarify the effect of polluted water on genetic processes of Tilapia (Tilapia zilli) by estimating chromosomal aberration test in somatic cells.

\section{MATERIALS AND METHODS}

Mature Tilapia zillii fishes of both sexes used in this study $(10-15 \mathrm{~cm}$ in length and 80100 gm body weight) were collected and transported to the laboratory from three different zones, (from both agricultural and industrial) localities according to these zones, fish were sorted into three studies in a living condition from an area in the Nile which is about $12 \mathrm{~km}$ distant from the southern boundaries of Benha district as shown in (Fig. 1). This area is totally far from any pollution sources (unpolluted locality) and was considered as control group. The second group, fish were collected alive from in Azbt El Prince village which is about $6 \mathrm{~km}$ distance from southern boundaries of Benha district as shown in (Fig. 1).

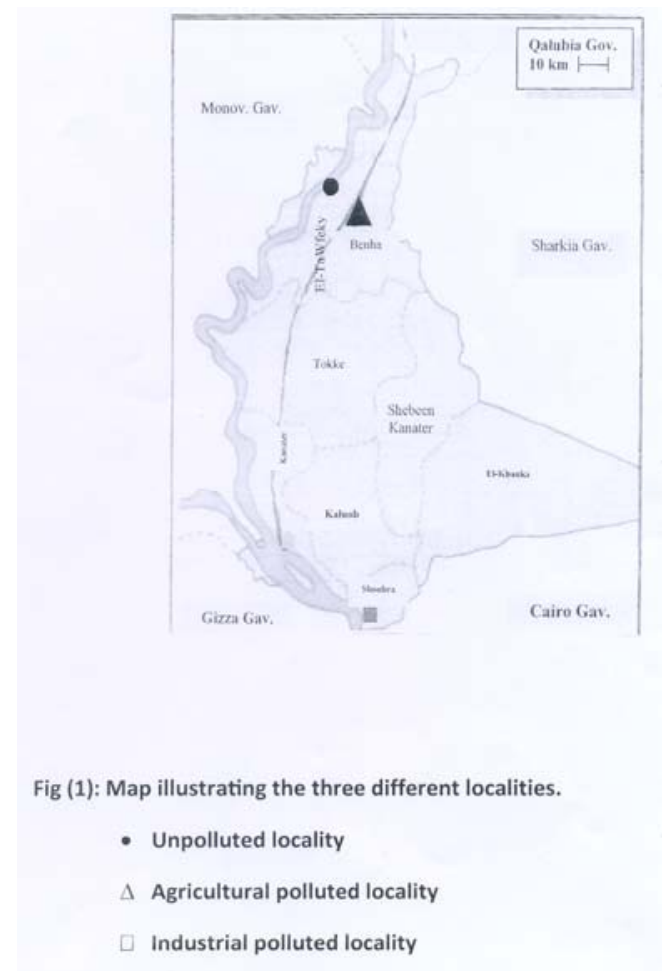

This area is considered as irrigated polluted locality (Agricultural pollution).The third group, fishes were collected from an area in Teraat EIShrakawia. This area close to an industrial drainage from the outlet of oil and detergent factory and chemical industrial factory. This area is considered as an industrial polluted locality. 
Water samples From the same localities of the collected fish, water samples were taken for chemical analysis to determine heavy metals concentration. The water samples were preserved by addition of $1 \mathrm{ml}$ concentrated nitric acid per liter until the time of analysis.

\section{Methods and techniques}

A- Analvsis of water sample: Heavy metals concentrations in water were measured as

ppm $(\mathrm{mg} / \mathrm{L})$ by atomic absorption spectrophotometer (AAS) with alteration of standard

burner head of AAS in relation to the light beam of examined metal (Pandya et al.,1985). Metals examined in the present study are copper,zinc, cadmium, mercury, lead, nickel, and Iron.

\section{B- Chromosomal preparation}

Metaphase spreads were prepared according to Yosida and Amano (1965) with some modifications. Spreads were stained in Geimsa solution. For each fish, 50 well metaphases spreads were examined randomly using XIOO oil immersion objective lenses. The data were statistically analyzed using the student's " $t$ " test Snedecor (1971) and also by using one-way analysis of variance ANOVA (Tu key test). Data were expressed as Mean \pm S.D for all experiments and the levels of significant were expressed as $\mathrm{P} \leq 0.05$.

\section{RESULTS}

Table 1 shows that analysis of water from the unpolluted locality is within the accepted permissible limit of the World Health Organization (WHO, 1984), while the mean $\pm \mathrm{SE}$ of iron, lead, mercury, cadmium and nickel exceeded the permissible limit in both agricultural and industrial locality.

\begin{tabular}{|c|c|c|c|c|c|c|c|}
\hline \multirow[t]{2}{*}{ The metal } & \multirow{2}{*}{$\begin{array}{l}\text { Unpolluted } \\
\text { locality } \\
\text { (Mean } \pm \mathrm{SE} \text { ) }\end{array}$} & \multicolumn{3}{|c|}{$\begin{array}{l}\text { Agricultural locality } \\
\qquad \text { (Mean } \pm \text { SE) }\end{array}$} & \multicolumn{3}{|c|}{$\begin{array}{l}\text { Industrial locality } \\
\qquad \text { (Mean } \pm \text { SE) }\end{array}$} \\
\hline & & $0 \mathrm{~m}$ & $300 \mathrm{~m}$ & $1000 \mathrm{~m}$ & $0 \mathrm{~m}$ & $300 \mathrm{~m}$ & $1000 \mathrm{~m}$ \\
\hline Iron & $0.195 \pm 0.050$ & $1.950 \pm 0.028$ & $1.450 \pm 0.033$ & $1.400 \pm 0.066$ & $3.850 \pm 0.434$ & $2.440 \pm 0.237$ & $2.500 \pm 0.066$ \\
\hline Lead & $0.015 \pm 0.007$ & $0.105 \pm 0.010$ & $0.065 \pm 0.003$ & $0.065 \pm 0.003$ & $0.475 \pm 0.016$ & $0.325 \pm 0.013$ & $0.170 \pm 0.033$ \\
\hline Cadmium & - & $0.030 \pm 0.006$ & $0.030 \pm 0.006$ & $0.020 \pm 0.004$ & $0.185 \pm 0.017$ & $0.110 \pm 0.026$ & $0.080 \pm 0.006$ \\
\hline Zinc & - & $0.055 \pm 0.022$ & $0.055 \pm 0.022$ & $0.035 \pm 0.003$ & $0.195 \pm 0.003$ & $0.145 \pm 0.003$ & $0.030 \pm 0.006$ \\
\hline Copper & $0.040 \pm 0.006$ & - & - & - & $0.300 \pm 0.133$ & $0.255 \pm 0.023$ & $0.300 \pm 0.006$ \\
\hline Nickel & - & $1.450 \pm 0.033$ & $0.850 \pm 0.033$ & $0.700 \pm 0.066$ & $3.400 \pm 0.267$ & $2.650 \pm 0.033$ & $2.220 \pm 0.066$ \\
\hline Mercury & $0.040 \pm 0.008$ & $0.725 \pm 0.010$ & $0.680 \pm 0.006$ & $0.600 \pm 0.02$ & $4.410 \pm 0.167$ & $3.680 \pm 0.177$ & $2.790 \pm 0.006$ \\
\hline
\end{tabular}

Various chromosomal aberrations were observed in head kidney cells of Tilapia zillii collected from the different studied localities in both industrial and agricultural locality. Both numerical and structural types of chromosomal aberrations were identified in Table (2\&3). Structural aberrations included centromeric attenuation, Chromatid break, Chromatid gaps، Chromatid deletions, Fragmentation, Ring and end to end association (Fig. 2).

Table (2): The mean values of chromosomal and chromatid aberrations in head kidney cells of Tilapia Zillii in polluted water.

\begin{tabular}{|c|c|c|c|c|c|c|c|}
\hline \multirow{2}{*}{$\begin{array}{l}\text { Aberration } \\
\text { type }\end{array}$} & \multirow{2}{*}{$\begin{array}{c}\text { Control } \\
(\text { Mean } \pm \text { SD) }\end{array}$} & \multicolumn{3}{|c|}{$\begin{array}{l}\text { Agricultural locality } \\
\qquad \text { (Mean } \pm \text { SD) }\end{array}$} & \multicolumn{3}{|c|}{$\begin{array}{l}\text { Industrial locality } \\
\qquad \text { (Mean } \pm \text { SD) }\end{array}$} \\
\hline & & $0 \mathrm{~m}$ & $300 \mathrm{~m}$ & $1000 \mathrm{~m}$ & o m & $300 \mathrm{~m}$ & $1000 \mathrm{~m}$ \\
\hline Deletion & $2.8 \pm 0.8$ & $13.2 \pm 4.0^{*}$ & $10.8 \pm 2.2^{\star}$ & $5.8 \pm 0.8^{*}$ & $1.7 \pm 1.1$ & $1.3 \pm 0.6$ & $2.6 \pm 1.1$ \\
\hline
\end{tabular}


Table (3): The mean values of numerical aberrations and mitotic index in head kidney cells of Tilapia Zillii in polluted water.

\begin{tabular}{|c|c|c|c|c|c|c|c|}
\hline \multirow{2}{*}{$\begin{array}{l}\text { Aberration } \\
\text { type }\end{array}$} & \multirow{2}{*}{$\begin{array}{c}\text { Control } \\
\text { (Mean } \pm \text { SD) }\end{array}$} & \multicolumn{3}{|c|}{$\begin{array}{l}\text { Agricultural locality } \\
\qquad \text { (Mean } \pm S D)\end{array}$} & \multicolumn{3}{|c|}{$\begin{array}{l}\text { Industrial locality } \\
\qquad \text { (Mean } \pm S D \text { ) }\end{array}$} \\
\hline & & $0 \mathrm{~m}$ & $300 \mathrm{~m}$ & $1000 \mathrm{~m}$ & $0 \mathrm{~m}$ & $300 \mathrm{~m}$ & $1000 \mathrm{~m}$ \\
\hline Monosomic & $0.8 \pm 0.8$ & $3.8 \pm 0.4^{*}$ & $3.4 \pm 0.5^{*}$ & $3.0 \pm 0.3^{*}$ & $0.6 \pm 6.8^{*}$ & $0.6 \pm 5.2^{*}$ & $0.4 \pm 4.3^{*}$ \\
\hline Polyploidy & $2.6 \pm 0.9$ & $8.6 \pm 2.0^{*}$ & $7.0 \pm 1.6^{*}$ & $4.6 \pm 1.4^{*}$ & $9.8 \pm 1.3^{*}$ & $9.4 \pm 1.9^{*}$ & $5.4 \pm 1.3^{*}$ \\
\hline Mitotic indix & $120.4 \pm 2.9$ & $90.0 \pm 6.8^{*}$ & $85.0 \pm 6.7^{*}$ & $88.0 \pm 7.3^{*}$ & $99.2 \pm 3.8^{*}$ & $89.4 \pm 6.2^{*}$ & $92.8 \pm 4.9^{*}$ \\
\hline
\end{tabular}

Stickiness is considered as a sort of chromosomal "agglutination" of unknown nature which results in a pycnotic or sticky appearance of chromosomes. Stickiness may give rise to sticky adhesion between two or more chromosomes and to formation of sticky bridges at anaphase (Fig. 2).

While numerical aberrations included monosomy and polyploidy (Fig. 3). The current study represented revealed that there is a very highly significant increase in the mean values of chromosomal aberrations between control fishes and fishes were taken from industrial polluted area. Also there is a significant increase in the mean value between fishes of control group and those which were taken from agricultural polluted water.
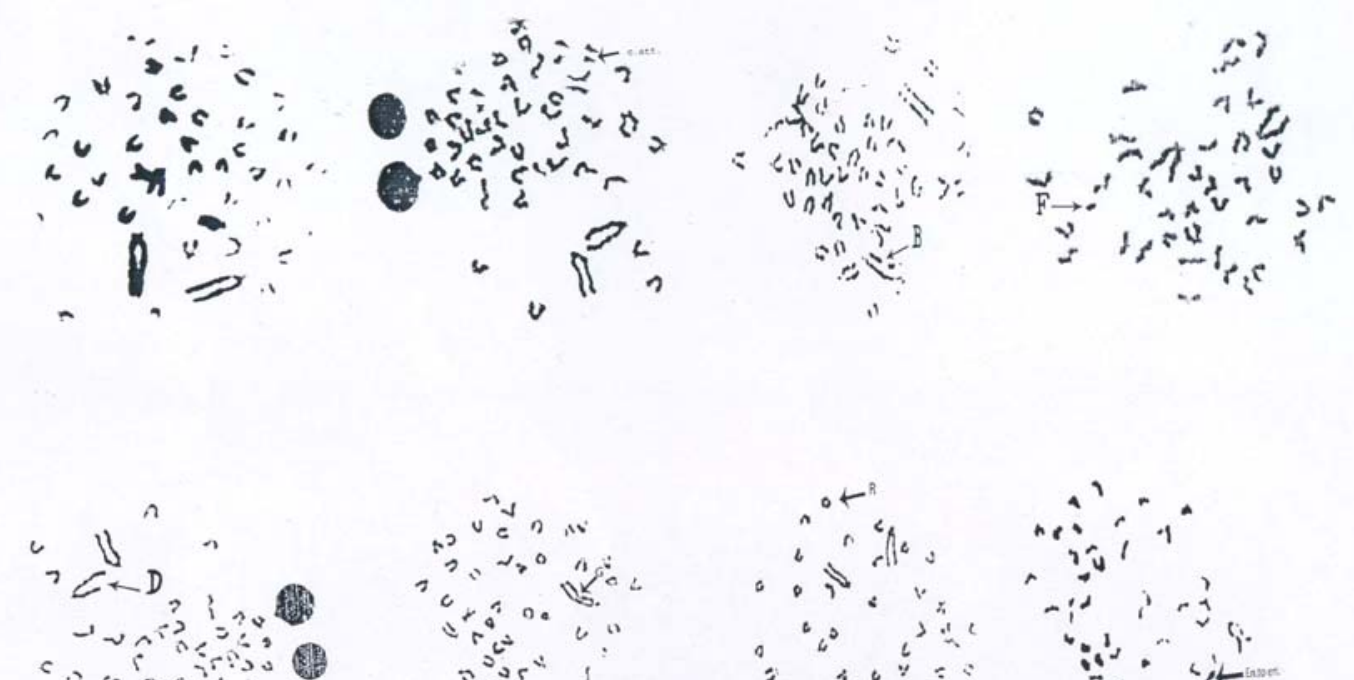


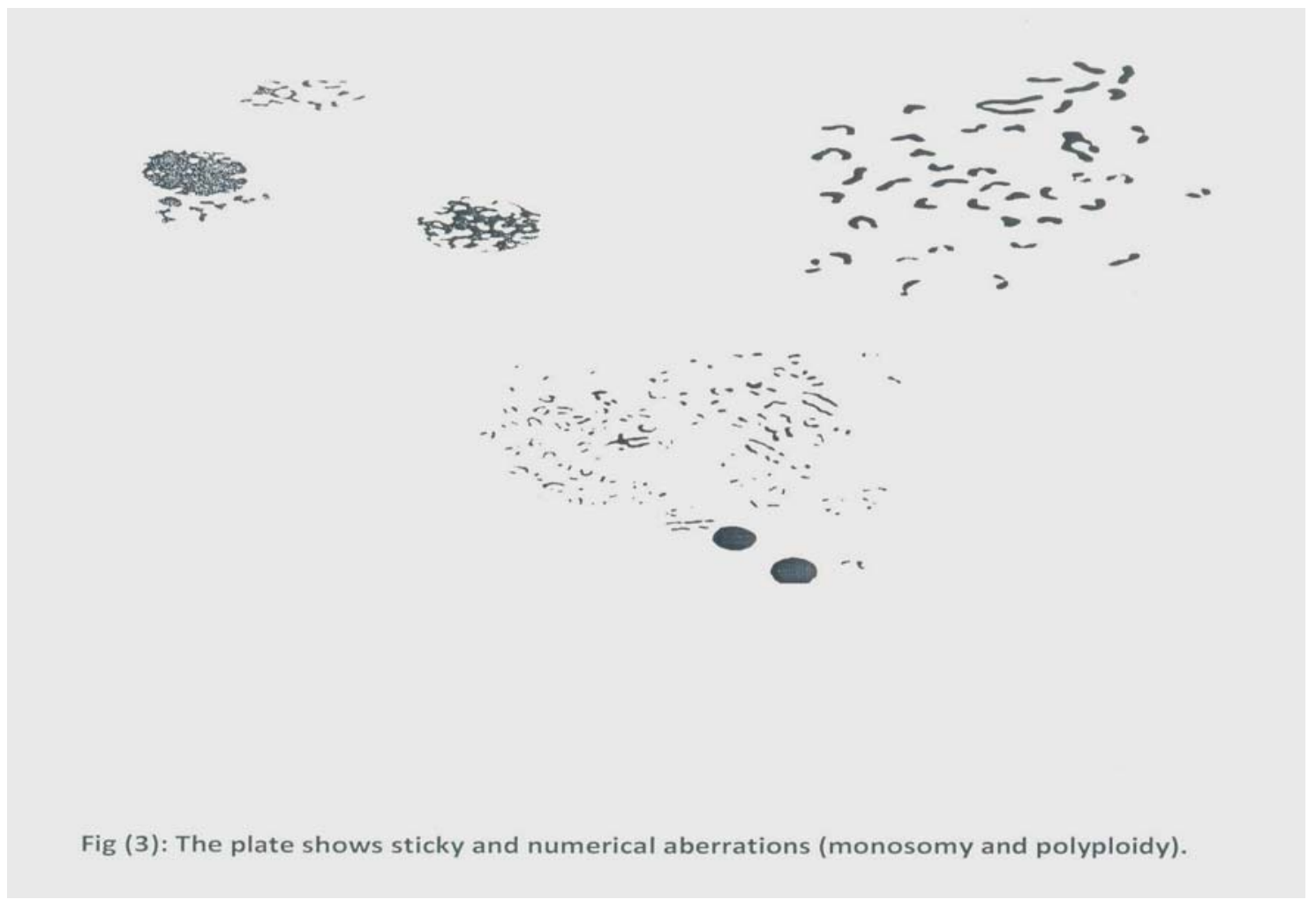

\section{DISCUSSION}

Environmental contamination of water become a threat to continued existence of many plants and animals communities and may ultimately threaten the survival of human.

In the current study, analysis of water from unpolluted locality showed that iron, lead, cadmium, copper, zinc, and nickel are within the accepted permissible limit of World Health Organization (WHO, 1984). On the other hand, analysis of water from the agricultural locality exceeded the permissible limit for iron, lead, cadmium, nickel and mercury at all distances while analysis of water from industrial locality exceeded the permissible limit for iron, lead, cadmium, nickel and mercury at all distances. Zinc was within the permissible limit of WHO in both the agricultural and industrial polluted water. The genotoxic effects of heavy metals found in the present 
investigation are similar to studies of Chandra and Bukhash (2004), who found that both cadmium chloride $(\mathrm{CdCh})$ and azadirachtin (Aza) induced genotoxicity in $\mathrm{O}$. mossambicus, the former in greater quality than that produced by Aza. Ferraro et al. (2004). found that tributylin and inorganic lead (Pbll) were potentially mutagenic on the fish $\mathrm{H}$ malabaricus.

In the present study, both industrial and agricultural water pollution caused as increase in the frequency of chromosomal aberrations but the frequency in the industrial pollution was higher than the agricultural pollution. The mean values of deletions, gaps and fragmentaion showed that, there was a highly significant increase of such aberrations in the agricultural locality, while the industrial locality showed a highly significant increase of break, centromeric attenuation, ring and stickness at all distances $(0 \mathrm{~m}, 300 \mathrm{~m}, 1000 \mathrm{~m})$. Lowley and Brooks، (1963) revealed that alkylating agents were known to cause chromosomal breakage by binding to DNA regions rich in guanine-cytosin pairs causing these to become unstable. Mathew and Jahgeedar (2003) recorded that the percentage of total metaphase spreads with,chromosomal aberrations was increased with increasing the concentration levels of different doses of mercuric nitrate, these aberrations included breaks, fragments, dicentric and ring type chromosomes.

Also, the present investigation revealed that there was a significant decrease in mitotic index for all fish samples when compared with control, this agree with a study of Barbosa et al. (2010), who detected a significant changes in the frequency of chromosome aberrations and in the mitotic index compared to negative control, the comet assay showed a statistically significant alteration in the level of DNA breaks of $O$. niloticus and chemical analysis detected an increase in heavy metal levels in different sampling periods. Similar results were recorded by Samma (2001) who fund that exposure of Chrysichthyl auratus and Lobes 'hori to water containing carbamate besticide (Saturn) for $72 \mathrm{~h}$, one week and two weeks duration resulted in a highly significant increase in the incidence of total chromosomal aberrations and significant decrease in mitotic index when compared with control of both fishes. Significant increase over and above negative control in the frequency of micronuclei was observed in fishes exposed to metal compounds, the order of induction of micronuclei frequency and toxicity was $\mathrm{As}>\mathrm{Hg}>\mathrm{Cu}$, Kamleset and Sunil (2009).

Deletion and centomeric attenuation were the most observed structural aberrations in the examined metaphases in the agricultural water pollution while break and centomeric attenuation were the most observed abnormality in the Industrial water pollution. The current data agree with the results reported by Bovero et al. (2002) who studied the effect of two geographically distant pollutions of chironomus riparius (Syn.Thummi) from two environmentally polluted sites (Santena, Italy and Varna Bulgaria) and found numerous somatic and inherited chromosomal aberrations (inversions, deletions and deficiencies). Also the effect of delta methrin on the catfish, Clarias garieinus, revealed that the frequency of chromosomal aberrations (chromatid gap, chromosome gap, haploidy and polyploidy) was represented in high percentage than the other type of aberration (Salama, 2001).

\section{REFERECES}

Alink, G.M.; Frederix-Walters, E.M.; Vander Gaag, M.A., Vasderkerkhoff, J.F.J. and Poels, C.L.M. (1980): Introduction of sister-chromatid exchanges in fish exposed to Rhine water. Mut. Res. 78: 369-374. 
AI-Sabti, k., Fijan, N. \& Kurelec, B. (1984): Frequency of chromosomal aberrations in the rainbow troute, (Salmogridneri, Rich) exposed to getergent benzene, Vet. Arh. 54, 83-89.

Barbosa, J.S.; Cabral, T.M.; Ferreira, D.N.; Agnez-Lima L.F. and Batistuzzo de Medeiros, S.R. (2010): Genotoxicity assessment in aquatic environment impacted by the presence of heavy metals. Ecotoxicology and Environmental Safety, 73(3): 320-325.

Bertello, L.A.C. (1978): Estudo citogenetics negenero Hoplias Grill, 1903 (Pisces Erythrinidae). Tese de doutorado., Universidade de sao Paulo, Faculdade demedicina de Ribedeivao perto., p 164.

Bovero, S.; Hankeln, T.; Michailova, P.; Schmidt, E.; Sella, G. (2002): Nonrandom chromosomal distribution of spontaneous breakpoints and satellite DNA clusters in two geographically distant populations of chironomus riparius. Genetica, 115(3): 273-281.

Chandra, P and Khuda-Bukhsh, A.R. (2004): Genotoxic effects of cadmium chloride and azadirachtin treated singly and in combination in fish. Ecotoxicology and Environmental Safety, 58(2): 194-201.

Ferarro, M.V.M.; Fenocchio, A.S.; Mantovani, M.S.; Ribeiro, C. de 0.; Cestari, M.M. (2004): Mutagenic effects of Tributyltin and inorganic lead (Pbll) on the fish $\mathrm{H}$. Malabaricus as evaluated using the comet assay and the piscine micronucleus and chromosome aberration tests. Genetics and Molecular Biology, 27(1): 103-107.

Haggag A.M., Marie, M.A.S. and Zaghloul, K.H. (1990): Seasonal effects of the industrial effluents on the Nile catfish CIarias gariepinus. J. Egypt Ger. Soc. Zool., 28(A): 365-391.

Hodson, P.V.; Whittle, D.M.; Wong, P.T.S.; Borgmann, U.; Thomas, R.H.; Chan, T.K.; Nriagu, J.D. and Bullett. D.J. (1984): Toxic contaminants in the great lakes. Niragh la. and Simmone M.S. (eds). John Wiley and Sons, New York, pp. 335-340.

Hose, J.E.; Cross, J.N.; Smith, S.G. and Diehl, D. (1987): Elevated circulating erythrocyte micronuclei in fishes from contaminated pits of southern California. Marine Environ. Res. 22: 167-176.

Kamlesh, K. Y. and Sunil, P. T. (2009): Sublethal exposure of heavy metals induces micronuclei in fish, Channa punctata. Chemosphere, 77(11): 1495-1500.

Karima, M. and Halima, A. (2002): Cytological studies on some Nile fish. J. Egypt. Ger. Soc. Zool., Vol. 36(c). Histology, Histochemistry and Genetics, 133- 144.

lowley, P.D. and Brooks, P. (1963): Further studies on the alkylation of nucleic acids and their constituent nucleotides. Biochem. J., 89: 137-138.

Mathew, N.P.A.; Jahageerdar, S. (2003): Effect of mercuric nitrate on the chromosomes of Channa punctatus. Fishery - technology - society of fisheries - Technologists - India (FishTechnol. Soc. Fish. Technol. India), 40(2): 77-82.

Pandya, C.B.; Parikh, DJ.; and Chatterjee, B.B. (1985): Accumulation and Inter-relationship of calcium and zinc in human kidney cortex., Environ. Res., 36: 81-88.

Pullin, P.S.U. and Meconnell, R.H. (1982): The biology and culture of Tilapias. Iclorm, Mcc. Makati, Metro. Mannila, Philippines, 389.

Salama, M.A.M. (2001): Experimental studies on the cytogenetic of a certain fresh water fish, Ph.D. Thesis, Zagazig Univ., ScL, 162pp.

Samma M.B. (2001): Cytogenetic studies on the effect of carbomate Herbicide "Ssturn" on Chrysichthy Auratus and Labes Hori fish. 1 Egypt Ger. Soc. Zool., Vol. 34 (c) Histology, Histochemistry and Genetics, 125-139.

Snedecor, G.W. (1971): Statistical Methods, 14th Edition. The Lowa state collage press ames'. Lowa. 
WHO (1984): Guide lines values\} WHO Bulletni\} guide lines for water quality Geneva Vol. 1.

Vosida, T.M. and Amano, K. (196S): Autosomal polymorphism in laboratory bred and wild Norway rats Rattus norvegicus found in Misima. Chromosoma, 16: 658-667.

Vu, R.L.; Aronson, M.M. and Nichols, W.W. (1981): High-resolution bands in human fibroblast chromosomes induced by Ictinomycin\} D. cytogenet. Cell Gent\} (31): 111114.

Zaghloul, K.H. (1OOl): Usage of zinc and calcium in inhibiting the toxic effect of copper on the African catfish (Clarias gariepinus.) J. Egypt Ger. Soc. Zool. 33(c): 99-120.

\section{ARABIC SUMMARY}

$$
\begin{aligned}
& \text { التأثير الوراثى الظلوي للمخلفات الصناعية والزراعية على سمكة البلطى الأخضر }
\end{aligned}
$$

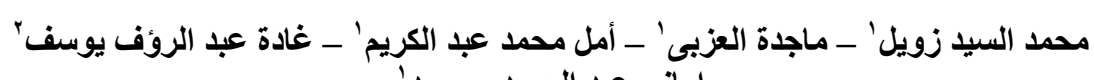

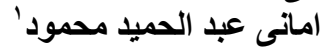

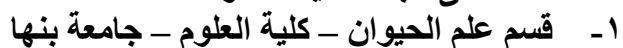

$$
\begin{aligned}
& \text { r- قسم علم الحيوان - كلية العلوم - جامعة المنوفية }
\end{aligned}
$$

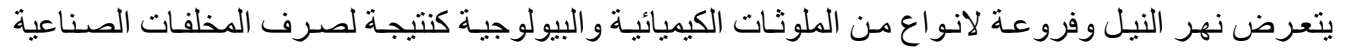

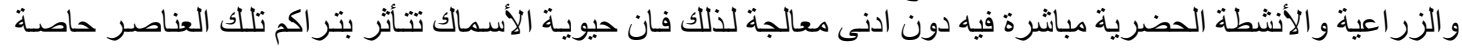

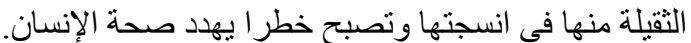

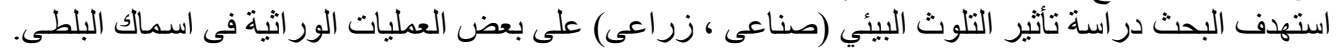

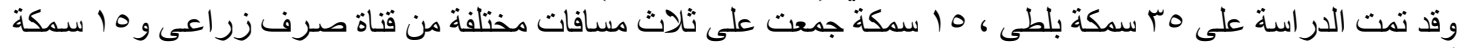

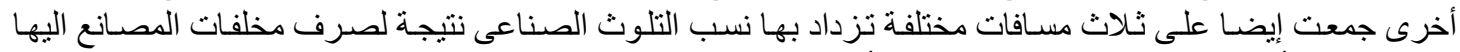

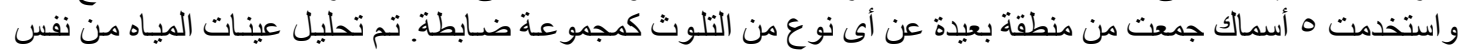

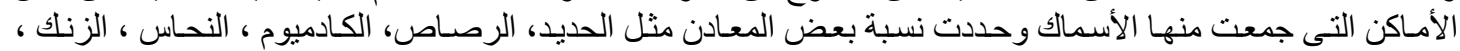

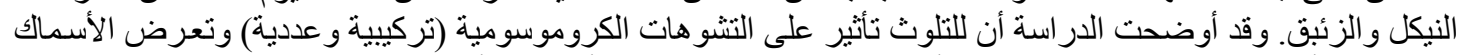

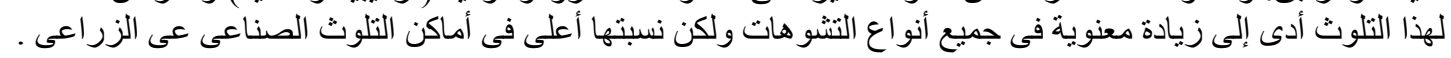

